\title{
Transformation of sensory organ identity by ectopic expression of Cut in Drosophila
}

\author{
Karen Blochlinger, ${ }^{1}$ Lily Yeh Jan, and Yuh Nung Jan \\ Howard Hughes Medical Institute and the Departments of Physiology and Biochemistry, University of California, \\ San Francisco, California 94143 USA
}

The loss of cut activity results in a change in neural identity in the peripheral nervous system so that the neurons and support cells of external sensory (es) organs are transformed into those of internal chordotonal (ch) organs. cut encodes a large nuclear homeo domain protein (Cut) that is expressed in the differentiated cells of es organs and their precursors but not in the cells of ch organs. We now analyze the effects of ectopic Cut expression in transformant lines of flies containing the Cut-coding sequences under inducible regulatory control. We demonstrate that ubiquitous Cut expression in embryos results specifically in the morphologic and antigenic transformation of ch organs into es organs. This effect appears to involve positive autoregulation of Cut expression. We conclude that Cut is not only necessary but sufficient for the specification of es organ identity in sensory organ precursor cells and their progeny. The specificity of Cut function to sensory organ cells involves the proneural loci daughterless and the achaete-scute complex.

[Key Words: Ectopic Cut expression; transformation; Drosophila; sensory organs]

Received April 2, 1991; revised version accepted April 26, 1991.

The establishment of neural identity is crucial to the development of a functional nervous system. The cut locus specifies the identity of a subset of neurons and support cells in the peripheral nervous system (PNS) of Drosophila: Embryonic lethal cut mutations result in the antigenic and morphologic transformation of external sensory (es) organs, such as chemoreceptors or mechanoreceptors, into internal chordotonal (ch) organs, which are thought to sense stretch (Bodmer et al. 1987).

Both es and ch organs consist of neurons with single dendrites innervating sensory structures formed by nonneuronal support cells (Hertweck 1931; McIver 1985; Zacharuk 1985; Hartenstein 1988). Each sensory organ is thought to originate from a single ectodermal precursor cell close to the final location of the sensory organ (Bate 1978; Bodmer et al. 1989); therefore, the cells within a sensory organ are lineally related (Bodmer et al. 1989). The differences between es and ch organs include their morphologic and antigenic properties, their positions with respect to the cuticle, and the division patterns of their precursors (Bodmer et al. 1987, 1989).

The cut locus codes for a nuclear homeo domain protein (Cut) and is expressed in all cells of es organs and their precursors but not in any cells of ch organs (Blochlinger et al. 1988, 1990). This is consistent with earlier mosaic analyses from which it was concluded that cut activity is required autonomously within es organs (Bod-

${ }^{1}$ Present address: Fred Hutchinson Cancer Research Center, Basic Sciences Division, Seattle, Washington 98104 USA. mer et al. 1987). cut is a large, genetically complex locus (Johnson and Judd 1979; Jack 1985; Liu et al. 1991); all cut mutations examined that affect es organ development are associated with either altered Cut protein distribution in the PNS or its incorrect subcellular localization (Blochlinger et al. 1990; Liu et al. 1991). The presence of a homeo domain in the predicted Cut protein and its nuclear localization imply that it regulates transcription, by analogy to other homeo domain proteins (for review, see Hayashi and Scott 1990). On the basis of these results we have postulated that Cut specifies sensory organ identity by establishing an es organ-specific program of development and differentiation in sensory organ precursor cells (Blochlinger et al. 1988). This hypothesis predicts that Cut expression in ch organ precursor cells would cause the transformation of ch organs into es organs. To address this issue we expressed Cut ectopically in stable lines of transformant flies containing the entire Cut-coding sequences under inducible regulatory control.

We also studied the effect of ectopic Cut expression in embryos lacking proneural gene activity. The expression patterns of the proneural genes define domains of cells that are competent to become neural precursors (for review, see Ghysen and Dambly-Chaudiere 1989; Jan and Jan 1990). Eliminating the function of any of the identified proneural genes leads to loss of neural tissue in the central nervous system (CNS) and the PNS: Loss of daughterless $($ da $)$ activity results in the absence of all neurons and support cells in the PNS/Caudy et al. 
1988a), whereas in embryos lacking the achaete-scute complex $(A S-C)$ all es organs are absent but ch organs are unaffected (Dambly-Chaudiere and Ghysen 1987). It is thought that the activation of Cut expression is controlled by the proneural genes. We performed experiments to test whether ectopic Cut expression can bypass the requirement for the genes of the $A S-\mathrm{C}$ or $d a$ in the development of es organs.

\section{Results}

\section{Ectopic expression of Cut from hsp70-Cut constructs}

A construct (hsCut, Fig. 1A), containing the entire Cutcoding sequences inserted between the $5^{\prime}$ - and $3^{\prime}$ - regulatory sequences of the $h s p 70$ gene in a P-element vector, was injected into embryos, and several independent, stably transformed lines were obtained. A brief heat shock treatment of hsCut transformant embryos results in nuclear expression of Cut in all cells (Fig. 1B). Western blot analyses with anti-Cut antibodies show that two bands of $\sim 280$ and $320 \mathrm{kD}$ are specifically labeled in protein extracts of wild-type embryos (Fig. 1C, lane 1) (Blochlinger et al. 1990). In extracts from hsCut embryos after heat shock treatment, the intensities of both of these two bands are increased considerably, but their relative intensities are changed with the more slowly migrating species predominating (Fig. 1C, lane 2). This suggests that the Cut protein produced after heat shock treatment is qualitatively identical to that found in wild-type embryos. No constitutive ectopic expression was observed in the absence of heat shock treatment in the lines of flies containing the hsCut construct used in the experiments described here (data not shown).

Cut is first expressed in es organ precursors (Blochlinger et al. 1990). To determine the effects of ectopic Cut expression, wild-type embryos and embryos containing the hsCut construct were subjected to one or two brief heat shock treatments during the period when sensory organ precursors appear and start to divide $(5-9 \mathrm{hr}$ of development at $25^{\circ} \mathrm{C}$ ) (Bodmer et al. 1989; Ghysen and O'Kane 1989). The embryos were then left to develop until late embryogenesis (stage 15-16) (Campos-Ortega and Hartenstein 1985) when the PNS is differentiated, at which point the embryos were analyzed with respect to the morphologic and antigenic properties of the sensory organs present.

Each es organ contains at least one neuron and three specialized support cells of which the inner support cell forms a sheath around the tip of the dendrite and the two outer support cells produce the sensory process /such as a sensory bristle) and a circular socket at the base of the sensory process. The outer support cells are located within the epidermal layer, and the neurons and the inner support cell lie just beneath it. A ch organ consists of four cells: a neuron; the scolopale cell, which secretes a sheath around the dendrite and forms the scolopale; an intracellular array of densely packed microtubules surrounded by electron-dense material; and two other support cells, the cap cell and the ligament cell, which mediate the attachment of the ch organ to the body wall. All four cells of ch organs are located subepidermally. The

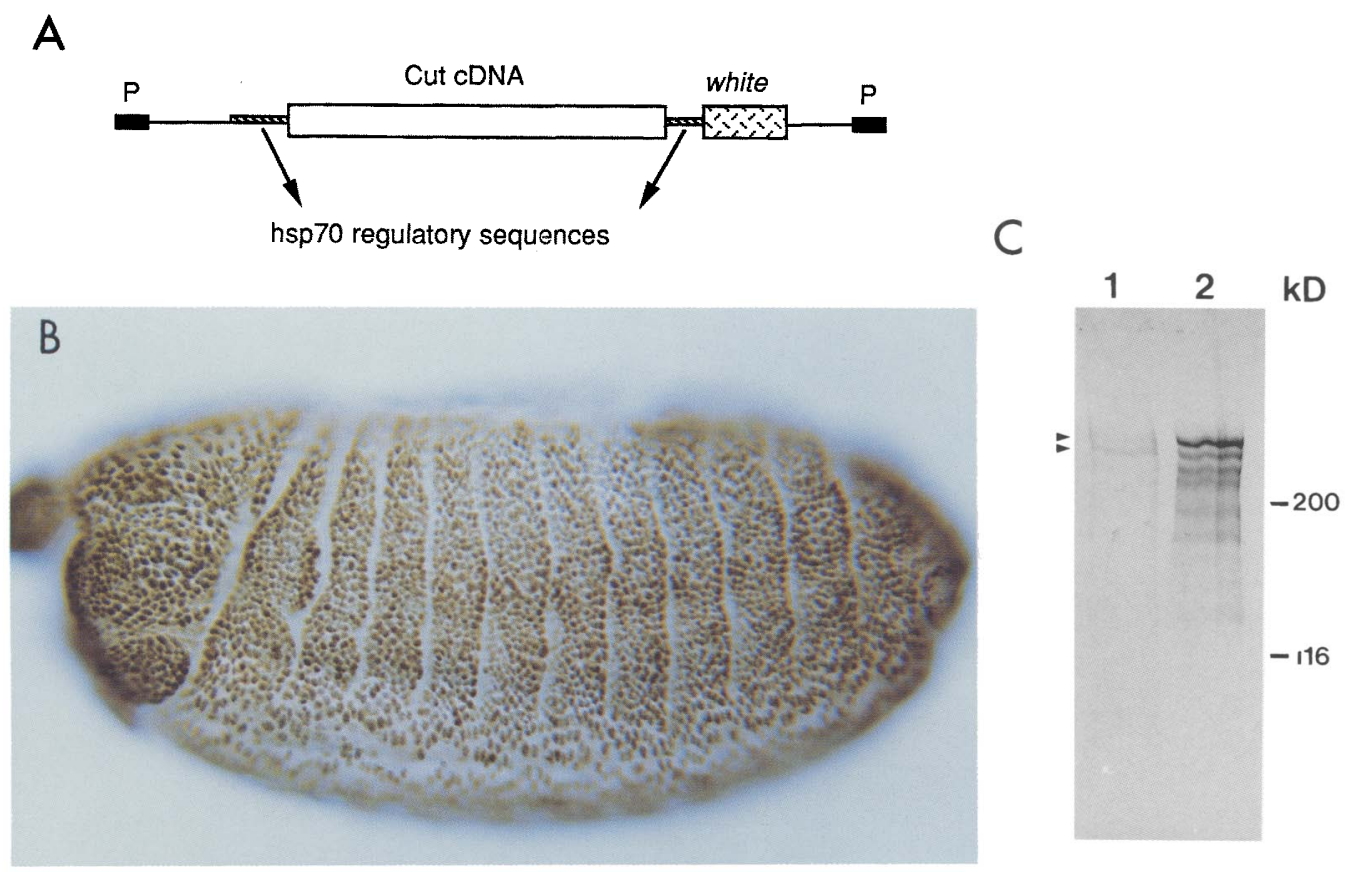

Figure 1. (A) Diagram of the hsCut construct. $(B)$ Lateral view of an embryo labeled with anti-Cut antibodies shortly after the heat shock treatment. Anterior is left; dorsal is up. (C) Western blot analysis with anti-Cut antibodies of protein extracts of 4- to 24-hr wild-type embryos (lane 1) and 1- to 16-hr hsCut (C2) embryos (lane 2). The faster migrating bands in lane 2 probably represent degradation products of Cut. 
neurons and support cells of es and ch organs can be identified and distinguished using antibodies or P-element insertion lines in which $\beta$-galactosidase is expressed in specific cell types. Five such markers were used in the studies described below.

\section{Ectopic Cut expression induces morphologic properties} of es organs in ch organs

Anti-horseradish peroxidase (HRP) labels the cell surface of all neurons (Jan and Jan 1982), as well as the scolopale at the tip of the ch dendrite and a dot at the tip of the es dendrite. Figure $2 \mathrm{~A}$ is a diagramatic representation of the four clusters of neurons (blue) and support cells found in an abdominal hemisegment. The dorsal cluster contains only es organ cells, whereas the other clusters contain both es organ and ch organ cells. Figure 2, B and C shows the lateral and part of the dorsal cluster of an abdominal hemisegment of a wild-type embryo (Fig. 2B) and an hsCut embryo (Fig. 2C) labeled with anti-HRP subsequent to the heat shock treatment described above. The heat shock treatment has no apparent effect on the pattern of sensory neurons in wild-type embryos (Fig. 2B). In hsCut embryos, however, the group of five ch neurons and scolopales in the lateral cluster /solid arrowhead in Fig. 2B) is absent and a new cluster of anti-HRP positive cells appears in a position posterior and slightly ventral to the es organs of the dorsal cluster (Fig. $2 \mathrm{C}$, open ar- rowhead). As described below, this new cluster probably originates from the precursors of the lateral ch organs. Lineage analyses and studies of DNA replication patterns suggest that the sensory organs form near the position of their respective precursor cells (Bate 1978; Bodmer et al. 1989). The five lateral ch organs appear to be an exception because the patterns of $\beta$-galactosidase expression in two P-element insertion lines in presumptive sensory organ precursors suggest that the precursors of the lateral ch organs are initially located more dorsally |Ghysen and O'Kane 1989). However, the cap cells of the lateral ch organs contact the epidermis at the position originally occupied by the precursor cells /V. Hartenstein, pers. comm.), and as the lateral ch organs shift ventrally relative to the body wall during development, the cap cells elongate (Hartenstein 1986). Therefore, the position of the new cluster of HRP-positive cells is consistent with it deriving from the precursors of the lateral ch organs.

The cells in the new cluster morphologically resemble neurons of es organs, rather than those of ch organs, both in the arrangement of the cells and in the absence of associated scolopales. Also, es-specific dots can be detected in another focal plane (see below). These observations could be explained by a transformation of ch organs into es organs.

We further investigated the morphologic properties of the new cluster of anti-HRP-labeled cells by labeling them with mAb21A6, a monoclonal antibody that de-

A

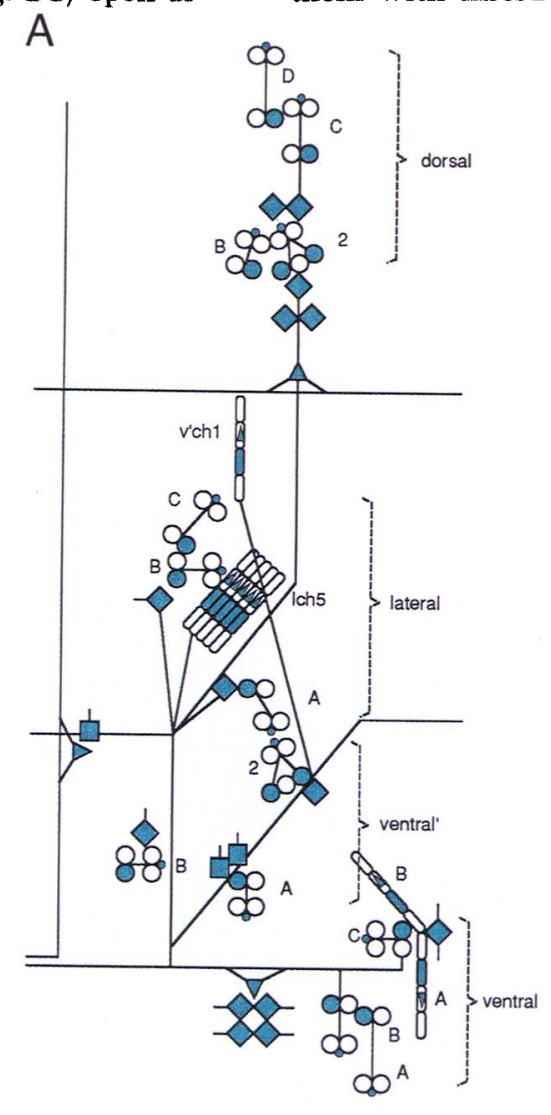

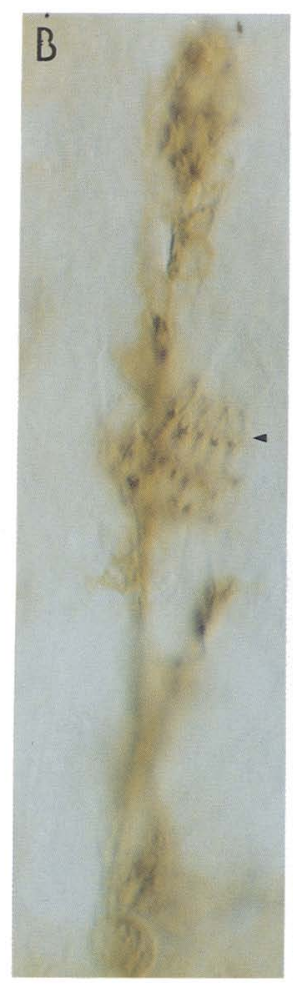

w.t.

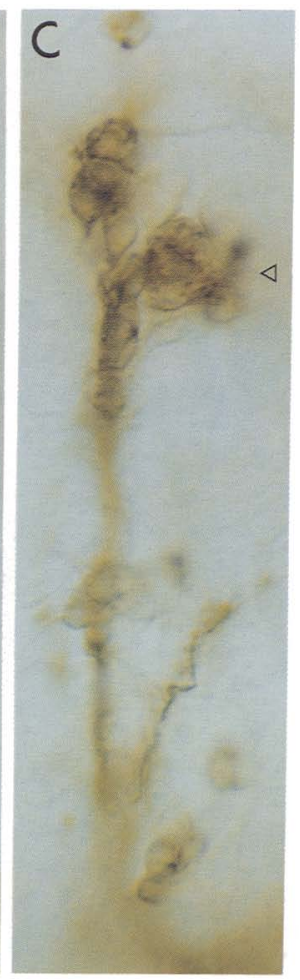

hs Cut 
tects an antigen in the extracellular dendritic cap surrounding the tip of sensory dendrites (Zipursky et al. 1984; Pollack 1985). mAb21A6 labels exclusively a dot at the tip of the es dendrite and the scolopale at the tip of the ch dendrite (indicated in red in Fig. 3A), providing one of the clearest distinctions between es and ch organs. The two different focal planes of a wild-type embryo after heat shock treatment stained with mAb21A6 (Fig. 3C and $3 \mathrm{D}$ ) illustrate the morphologies and positions of the dots in the epidermis (Fig. 3D) and the subepidermal location of the scolopales (Fig. 3C).

In an embryonic lethal cut mutant embryo (Blochlinger et al. 1990) es organs are transformed into ch organs: Scolopales are found in the place of dots and they are all in the same subepidermal focal plane as the scolopales of the wild-type ch organs (Fig. 3B). Conversely, in heat shock-treated hsCut embryos labeled with mAb21A6 the scolopales are absent from the lateral cluster and dots are found in the region of the new cluster identified with anti-HRP (Fig. 3E, open arrowhead), pro- viding further evidence of a morphologic transformation of ch neurons into es neurons.

\section{Ectopic Cut expression induces antigenic properties of es organs in ch organs}

To determine the antigenic properties of the new cluster of cells posterior to the dorsal cluster, we examined the $\beta$-galactosidase expression pattern of the P-element insertion line A1 2nd 29 in hsCut embryos. In this line lac $Z$ is specifically expressed in the outer support cells (tormogen and trichogen) of all embryonic es organs (Hartenstein and Posakony 1990; E. Bier and R. Bodmer, pers. comm.) (indicated in solid red in Fig. 4A). In addition to the strong $\beta$-galactosidase expression in outer support cells of es organs (Fig. 4B), lacZ is sometimes expressed weakly in some of the lateral ch cap cells (Fig. 4B, arrow) and one or two nearby epidermal cells (Fig. 4B, solid arrowhead). This pattern of expression is not affected by heat shock treatment of wild-type embryos
A

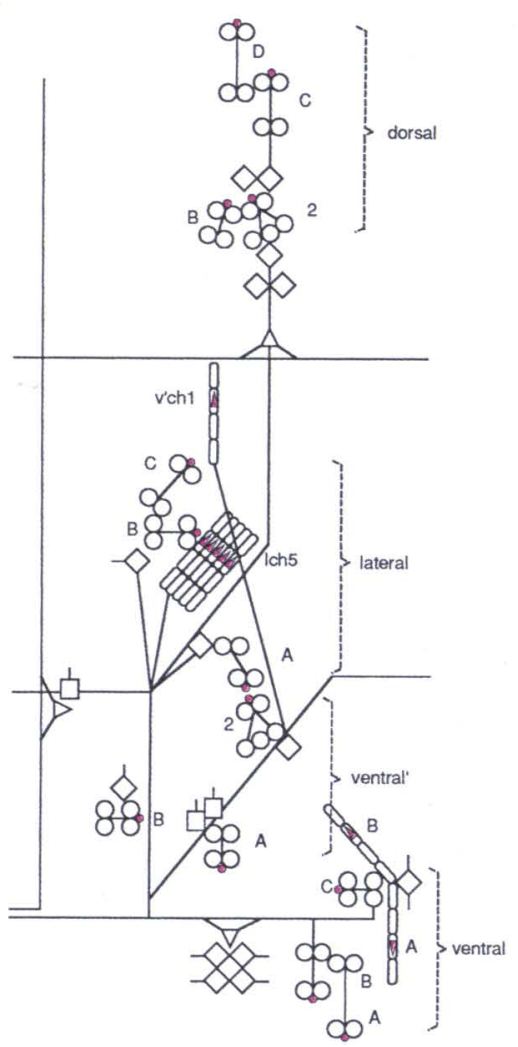

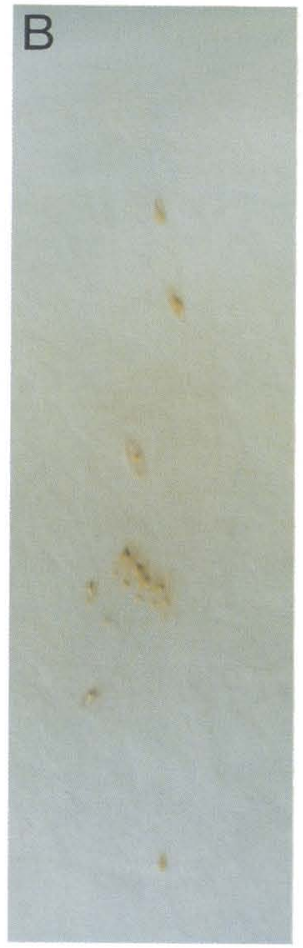

$c t \mathrm{C} 145$
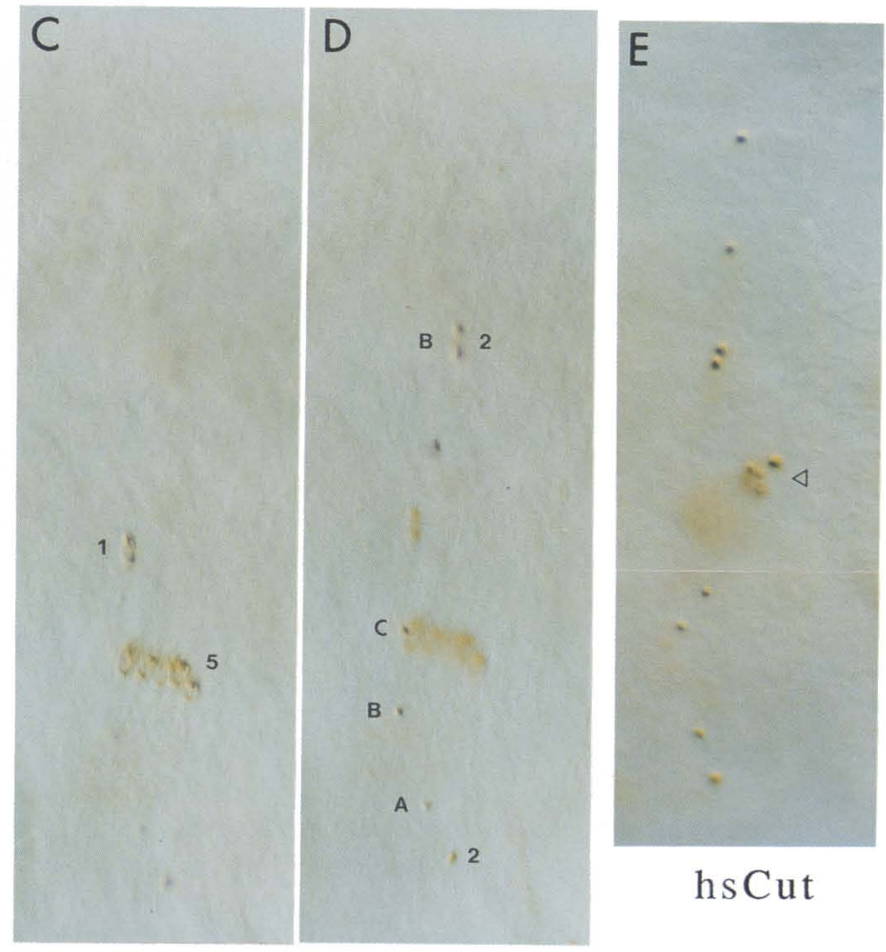

w.t.

Figure 3. (A) Schematic representation of the neurons and support cells in the PNS in an abdominal hemisegment (for details, see Fig. 2A). es-Specific dots and ch-specific scolopales are indicated in red. (B) View of the lateral and dorsal clusters of an abdominal hemisegment of a $c t^{C 145}$ mutant embryo labeled with mAb21A6. $(C$ and $D)$ View in two focal planes of the lateral and dorsal clusters of an abdominal hemisegment of a wild-type embryo (w.t.) labeled with mAb21A6 after heat shock treatment. Letters and numbers refer to letters and numbers in $A$. $|E|$ View of the lateral and dorsal clusters of an abdominal hemisegment of an hsCut embryo labeled with mAb2lA6 after heat shock treatment. The open arrowhead indicates a new cluster of es-specific dots. The diffuse staining observed in the lateral region corresponds to the cells synthesizing the antigen recognized by mAb21A6. 
Figure 4. (A) Schematic representation of the neurons and support cells in the PNS in an abdominal hemisegment (for details, see Fig. 2A). Outer support cells of es organs expressing $\beta$-galactosidase in the P-element insertion line A1 2nd 29 are solid red. The chordotonal cap cells, which are sometimes weakly labeled by anti- $\beta$-galactosidase, are stippled red. $(B$ and $C$ ) Views of the lateral and part of the dorsal clusters of an abdominal hemisegment in a wild-type embryo (w.t.) $(B)$ and an hsCut embryo $(C)$ labeled with anti- $\beta$-galactosidase after heat shock treatment. Letters and numbers refer to letters and numbers in $A$. The open arrowhead in $C$ indicates a new cluster of $\beta$-galactosidase-expressing cells. The arrow in $B$ indicates two cap _ulls (left), and the solid arrowhead points to two epidermal cells (right) expressing low levels of $\beta$-galactosidase.

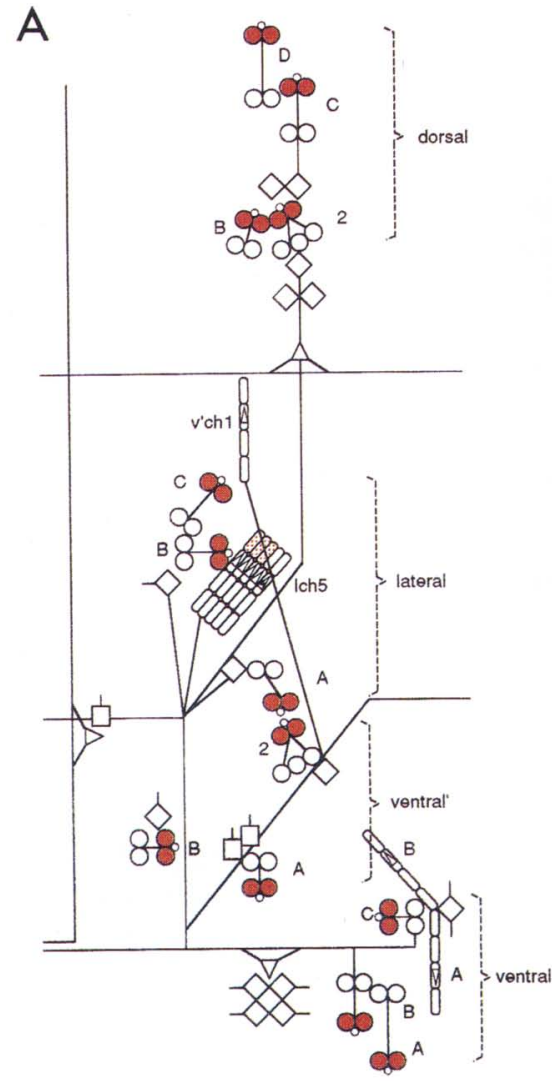

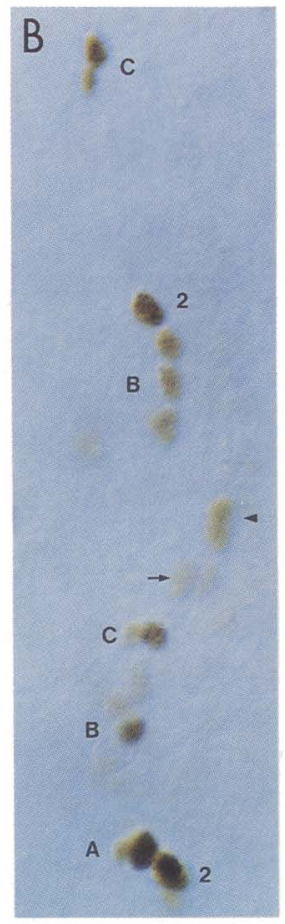

w.t.

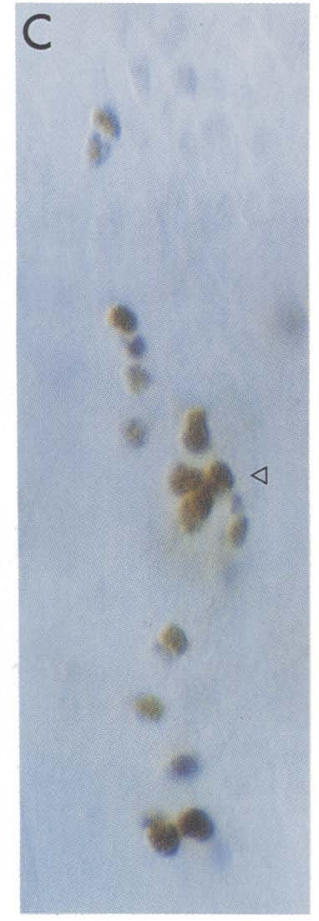

hsCut
(Fig. 4B). In embryonic lethal cut mutant embryos containing the Al 2nd 29 insertion, a dramatic reduction in $\beta$-galactosidase expression is observed $(\mathrm{R}$. Bodmer and Y.N. Jan, unpubl.). In embryos containing both the A1 2nd 29 insertion and hsCut, strong $\beta$-galactosidase expression is seen in some of the cells in the position of the new cluster identified with anti-HRP (Fig. 4C, open arrowhead). Also, an additional one or two labeled cells are observed in the lateral cluster, probably corresponding to the transformed $\mathrm{v}^{\prime} \mathrm{ch} 1$ organ. The morphologic characteristics of the additional $\beta$-galactosidase-expressing cells and their positions within the epidermal layer are indistinguishable from those of outer support cells of es organs.

We also labeled hsCut embryos with mAb49C4, a monoclonal antibody that stains the cytoplasm of the neurons of four of the five lateral ch organs and the ventral ch organ B (Fig. 5A; shown in green in Fig. $5 B$ ). In embryonic lethal cut mutant embryos the mAb49C4 antigen is expressed in some of the transformed es neurons (Bodmer et al. 1987). Conversely, most of the mAb49C4 staining is absent in hsCut embryos; often the only staining remaining is in parts of the axon (data not shown). Infrequently, one or more of the cell bodies are still labeled. However, the dendrites are usually directed toward the surface of the embryo, as shown in two different focal planes in Figure 5, C and D (arrows). The loss of expression of the ch neuron-specific antigen recognized by mAb49C4 is consistent with an antigenic transformation of ch neurons into es neurons.

\section{Cut expression pattern of hsCut embryos}

Cut is expressed in all cells within es organs: The two outer support cells are intensely labeled (Fig. 6A, solid red circles); the inner support cell and the neurons are moderately labeled (stippled red circles) (Blochlinger et al. 1988, 1990). Figure 6, B-D, shows a wild-type (Fig. 6B) and two different hsCut embryos (Fig. 6C and D) labeled with Cut antibodies subsequent to the heat shock treatment. At this point it is important to emphasize that the immunocytochemistry is performed several hours after the heat shock treatment when the ectopically supplied Cut has been degraded, as is indicated by the lack of ubiquitous labeling (cf. Fig. 1B). However, Cut is expressed in the cells in the new cluster posterior to the dorsal cluster (open arrowheads). This suggests that the ectopically supplied Cut protein has resulted in the activation of expression of the endogenous cut locus in $\mathrm{ch}$ organ precursors and that this expression is then maintained in their progeny (see below). The number of Cutexpressing cells in this new cluster is variable, which probably reflects differences in the age of the embryos at the time of the heat shock treatment. Generally, two 


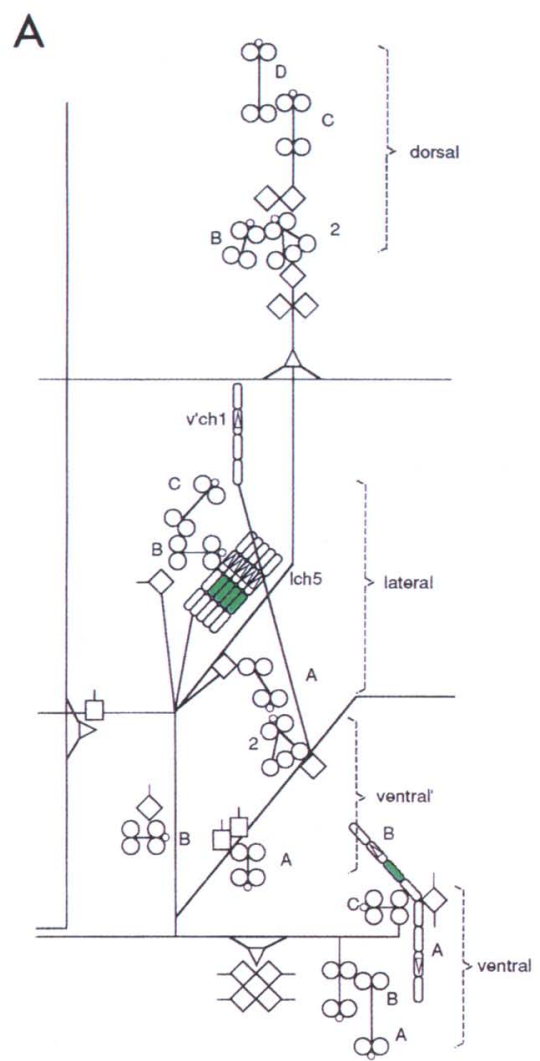

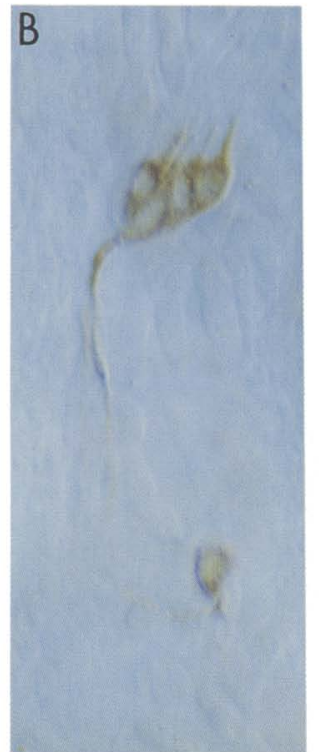

W.t.

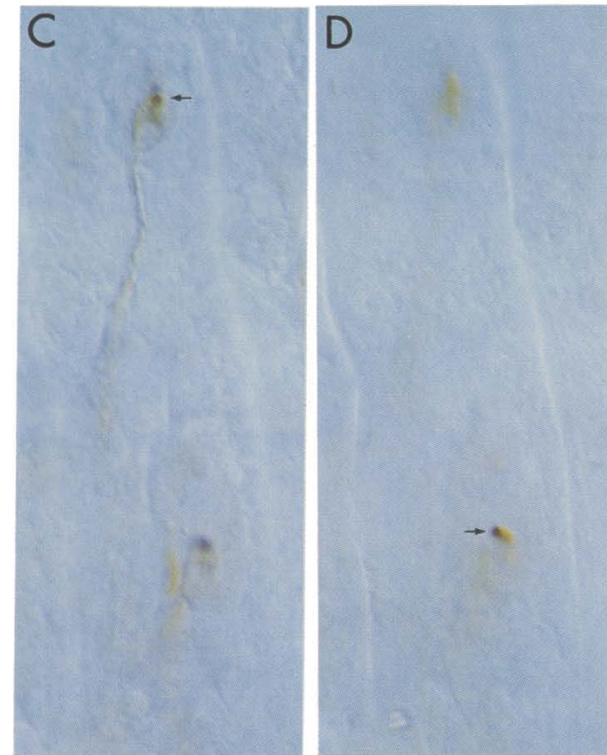

hs Cut

Figure 5. (A) Schematic representation of the neurons and support cells in the PNS in an abdominal hemisegment (for details, see Fig. 2A). Ch neurons labeled by mAb49C4 are indicted in green. (B) View of the ventral, ventral', and lateral clusters of an abdominal hemisegment of a wild-type (w.t.) embryo labeled with mAb49C4 after heat shock treatment. $(C$ and $D)$ Views of two different focal planes of the ventral, ventral', and lateral clusters of an abdominal hemisegment of an hsCut embryo labeled with mAb49C4 after heat shock treatment. The arrows indicate dendrite projecting to the surface of the embryo.

heat shock treatments at $42^{\circ} \mathrm{C}$ for 15 min each results in a greater number of Cut-expressing cells in this new cluster than a single heat shock treatment at $37^{\circ} \mathrm{C}$ for 30 min (data not shown). The maximum number of Cutexpressing cells in the new cluster is $15-20$, consistent with the number of cells constituting the five lateral ch organs. Another salient feature of the Cut expression in this new cluster is that some of the cells are moderately stained, whereas others are intensely stained and are closer to the surface of the embryo, as is normally observed in es organs.

Cut is also expressed in other tissues besides es organs (Blochlinger et al. 1990), including six to eight subepidermal cells surrounding the site occupied by the tracheal pits earlier in development, which probably correspond to the tracheal histoblasts / the staining in this group of cells is often obscured by the overlying cells of the lateral CNS cluster and is not evident in Fig. 6B). The embryonic tracheal system forms from $\mathrm{T}$-shaped invaginations at the anterior and posterior spiracles and the tracheal pits, which then connect (Campos-Ortega and Hartenstein 1985). Later in embryogenesis, only the spiracles remain open to the outside; all the other openings are sealed off until early pupation when the tracheal his- toblasts form the adult tracheal system. We suggest that the cluster of Cut-expressing cells anterior to the lateral cluster of peripheral neurons in hsCut embryos (Fig. 6C and $D$, solid arrowhead) represents an expansion of the domain of putative tracheal histoblasts. It is not clear whether this expansion is the result of recruitment of additional cells or precocious proliferation of the original histoblasts.

\section{Cut positively regulates its own expression}

The continued presence of Cut protein in the transformed ch organ cells and the expanded domain of putative tracheal histoblasts, after the ectopically expressed Cut protein has disappeared from all other cells, represents either persistence of selectively stabilized protein or activation of the endogenous cut locus. To investigate the ability of Cut to regulate its own expression positively, the hsCut construct was introduced into a cut mutant background $\left(c t^{d b 10}\right)$ in which a cytoplasmic Cut protein is expressed (Blochlinger et al. 1990). After the heat shock treatment protocol described above, cytoplasmic staining is now observed in the group of cells posterior to the dorsal cluster (Fig. 6E, open arrowhead), as 
A

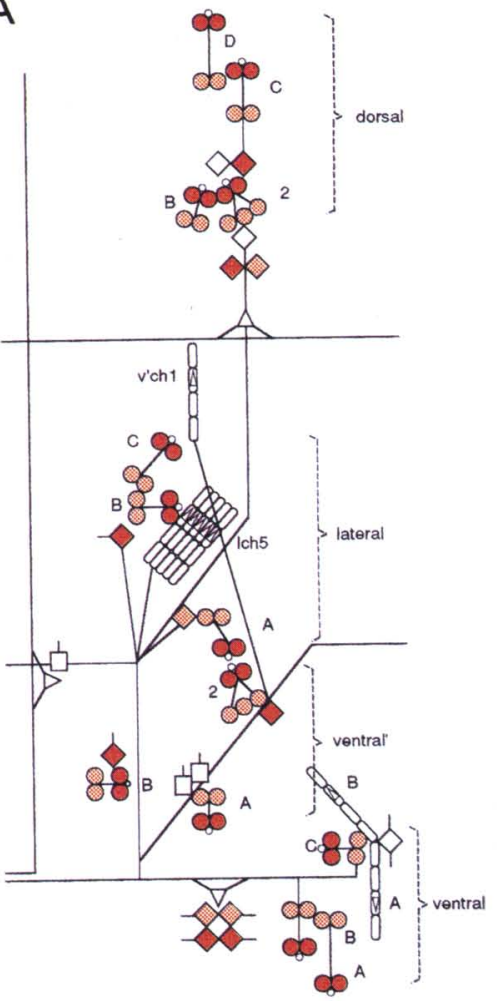

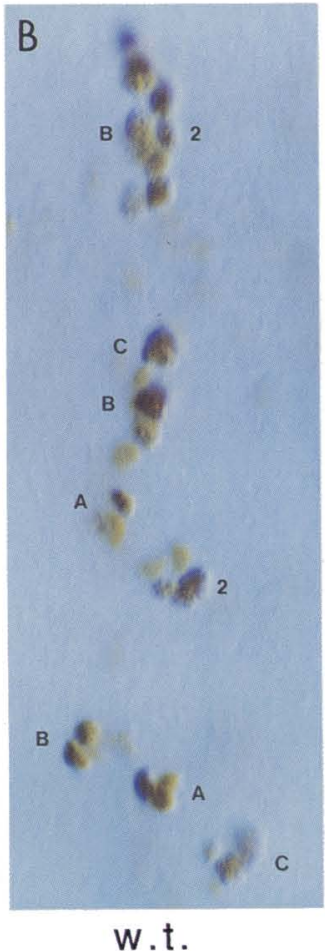

w.t.
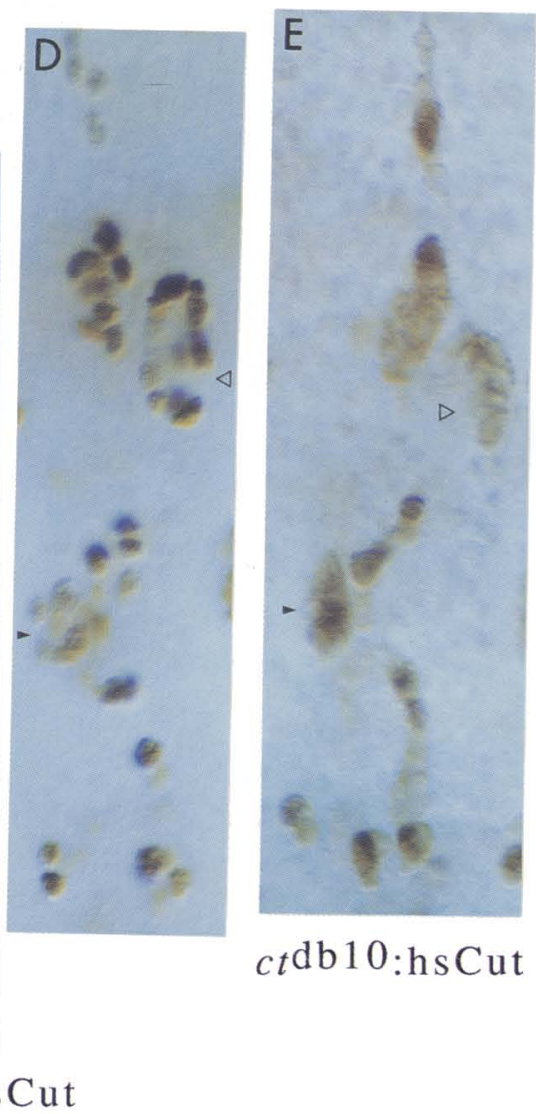

Figure 6. (A) Schematic representation of the neurons and support cells in the PNS in an abdominal hemisegment (for details, see Fig. 2A). Moderately anti-Cut-stained cells are depicted as stippled red symbols; darkly stained cells are shown as solid red symbols. $(B)$ View of part of the ventral, the ventral', the lateral, and part of the dorsal clusters of an abdominal hemisegment of a wild-type (w.t.) embryo labeled with anti-Cut antibodies after heat shock treatment. Letters and numbers refer to letters and numbers in $A$. $(C$ and $D \mid$ View of part of the ventral, the ventral', the lateral, and part of the dorsal clusters of an abdominal hemisegment of two different hsCut embryos labeled with anti-Cut antibodies after heat shock treatment. The open arrowheads indicate a new cluster of Cut-expressing cells; the solid arrowheads indicate the expanded domain of putative tracheal histoblasts. $(E)$ View of part of the ventral, the ventral', the lateral, and part of the dorsal clusters of an abdominal hemisegment of $c t^{d b 10}$ mutant embryo containing the hsCut construct labeled with anti-Cut antibodies after heat shock treatment. The open arrowhead indicates a new cluster of Cut-expressing cells; the solid arrowhead indicates the expanded domain of putative tracheal histoblasts. Note cytoplasmic staining.

well as in the expanded domain of putative tracheal histoblasts (solid arrowhead). This observation demonstrates that the ectopic Cut expression has directly or indirectly activated expression of the endogenous locus. $c t^{d b 10}$ is an embryonic lethal mutation that causes the transformation of es organs into ch organs because the Cut protein synthesized is cytoplasmic and nonfunctional (Blochlinger et al. 1990). In a parallel experiment to the one described above in which the $c t^{d b 10}$ embryos containing the hsCut construct were labeled with mAb21A6, scolopales typical of ch organs were seen both in the positions normally occupied by es organs and in the group of cells posterior to the dorsal cluster /data not shown). It appears that the transient expression of a functional Cut protein after heat shock treatment temporarily establishes es organ identity in all sensory organ precursors including the ch organ precursors (reflected by the aberrant position of their progenyl, but that the maintenance of this identity is contingent on the continued presence of cut activity, that is, a functional Cut protein encoded at the endogenous locus.

\section{Ectopic Cut expression in proneural mutants}

The results described above demonstrate that only in es and ch organ precursor cells and their progeny is the expression of Cut sufficient for the determination of es organ identity. This means that additional factors are required for cells to be competent to respond to Cut by differentiating es organ properties. Such factors may be encoded by the proneural genes, for example, $d a$ and the four genes of the $A S$-C. The activity of $d a$ is required for the formation of all peripheral neurons and sensory structures (Caudy et al. 1988a). In contrast, deletion of $A S$-C eliminates only es organs and does not affect ch organs (Dambly-Chaudiere and Ghysen 1987). To inves- 
tigate whether ectopic Cut expression can bypass the requirement for the genes of the $A S-\mathrm{C}$ or $d a$, the hsCut construct was introduced into genetic backgrounds mutant for either of these loci. The same heat shock protocol described earlier was used, and the embryos were subsequently labeled with anti-Cut antibodies. Figure 7A shows an embryo lacking zygotic da activity labeled with anti-Cut antibodies. As in wild-type embryos Cut expression is seen surrounding the anterior and posterior spiracles, in the Malpighian tubules, in the fragments of the CNS not deleted by the mutation, and in segmentally repeated groups of cells that probably are tracheal histoblasts. The same pattern of Cut expression is observed in embryos lacking the $A S$-C (Fig. $7 \mathrm{C}$ ). In da mutant embryos containing the hsCut construct no additional Cut-expressing cells resembling es organs are observed in the positions where es organs form in wild-type embryos (Fig. 7B). Similarly, no rescue of es organs is observed in $A S$-C mutant embryos containing the hsCut construct (Fig. 7D). However, a cluster of Cut-expressing cells dorsally (open arrowhead) and small groups of Cutexpressing cells in a ventral position in every segment (white arrow) are observed. Because deletion of the AS-C does not affect the ch organs, we suggest that these Cutexpressing cells represent the transformed ch organs. Finally, in both $A S-\mathrm{C}$ and da mutant embryos containing the hsCut construct the domain of putative tracheal histoblasts is considerably expanded (Fig. $7 \mathrm{~B}$ and D, solid arrowheads). We conclude that ectopic Cut expression is not sufficient to permit the development of any es organs in $d a$ mutant embryos; and in $A S$-C mutant embryos containing hsCut, es organs can form only in the place of ch organs. However, the ability of ectopic Cut expression to affect the domain of putative tracheal histoblasts is unchanged by either of these mutations.

\section{Discussion}

\section{Ectopic Cut expression transforms ch organs} into es organs

In the absence of cut activity, es organs are transformed into ch organs (Bodmer et al. 1987). Conversely, we show here that ectopic Cut expression, at the time when sensory organ precursors appear and start to divide, affects the identity of ch organs so that they display morpho-
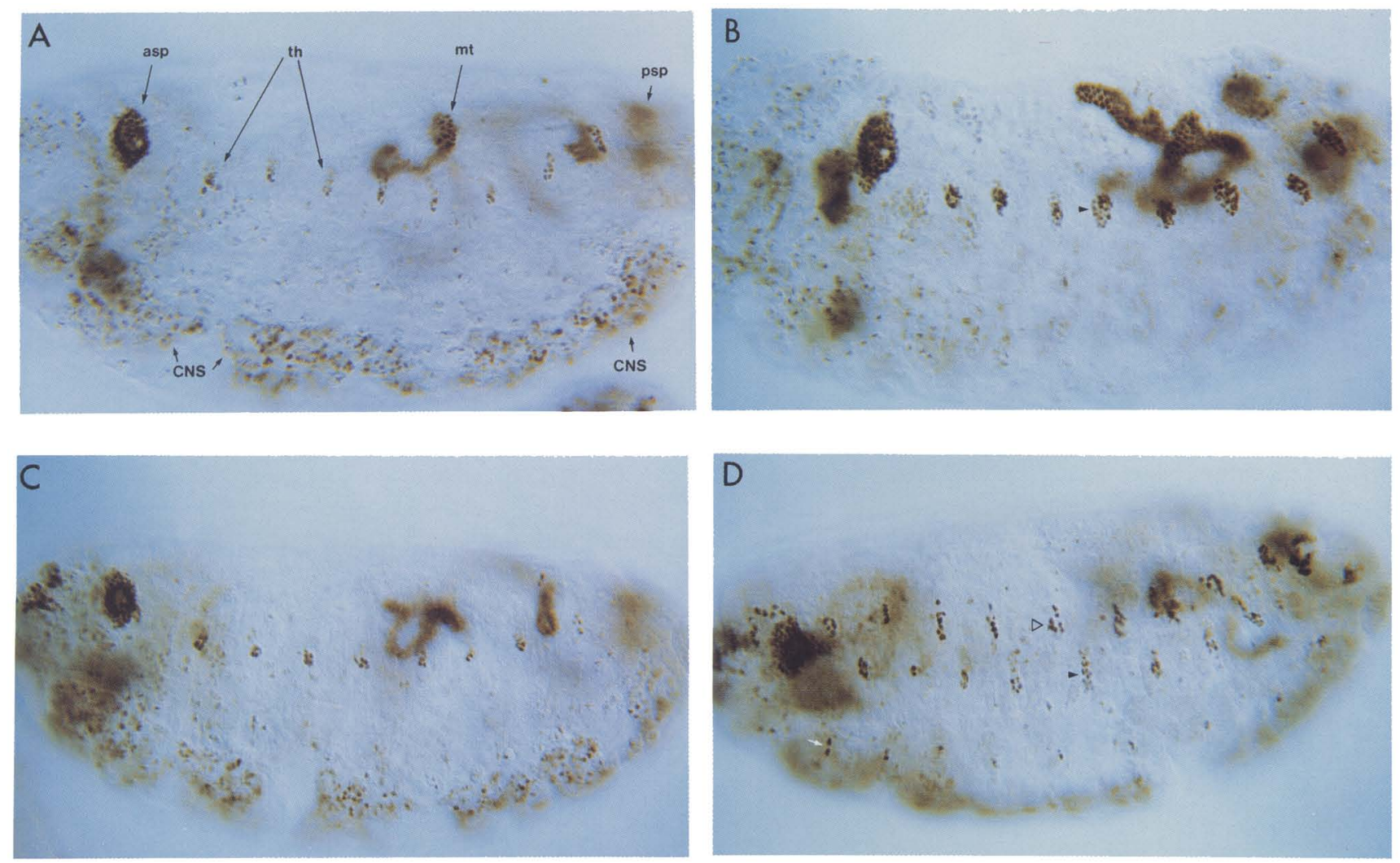

Figure 7. $(A$ and $C)$ Lateral view of a $d a(A)$ and an $A S-C(C)$ mutant embryo labeled with anti-Cut antibodies after heat shock treatment. (asp) Anterior spiracle; (psp) posterior spiracle; (mt) Malpighian tubules; (th) putative tracheal histoblasts. Anterior is left, dorsal is up. $(B$ and $D)$ Lateral view of a $d a(B)$ and an $A S-C(D)$ mutant embryo containing the hsCut construct labeled with anti-Cut antibodies after heat shock treatment. The open arrowheads indicate the new cluster of Cut-positive cells posterior and slightly ventral to the position of the dorsal cluster in wild-type embryos; the solid arrowheads indicate the expanded domain of putative tracheal histoblasts; the white arrow indicates a small group of cells that probably correspond to transformed ventral ch organs. 
logic as well as antigenic characteristics of es organs. After ectopic Cut expression the arrangement of the cells in the transformed ch organs is typical of es organs. This is confirmed by the change in the shape and orientation of the cap at the tip of the dendrite as revealed by mAb21A6. The change in antigenicity is documented by the partial or complete loss of expression of the ch organspecific antigen recognized by the mAb49C4 and activation of expression of es organ-specific protein Cut and $\beta$-galactosidase in the insertion line A1 2nd 29 (although a low level of $1 a c Z$ expression is sometimes observed in several of the cells of ch organs in Al 2nd 29, many more cells express $\beta$-galactosidase and at significantly higher levels after ectopic Cut expression). The acquisition of es organ properties by ch organ cells is observed in all heatshock-treated hsCut embryos but in none of the wildtype embryos. However, the extent of transformation varies with the severity of the heat shock treatment administered and the age of the embryos at the time of treatment. On the basis of this morphologic and antigenic transformation of ch organs into es organs after ectopic Cut expression, we conclude that Cut is sufficient for the specification of es organ identity in sensory organ precursors and their progeny.

\section{Positive autoregulation by Cut}

We have shown that ectopically synthesized Cut activates the expression of the endogenous cut locus in transformed ch organs and cells that appear to be tracheal histoblasts and that this expression is maintained. We have not determined whether this is a direct or indirect effect. In wild-type es organs Cut is expressed strongly in the outer support cells and moderately in the inner support cell and neuron (Blochlinger et al. 1990). Similar differences in the levels of Cut expression are seen in the transformed ch organs. This suggests that once the Cut expression is activated in precursor cells it may coordinate the different levels of Cut expression in the progeny cells. We have argued previously that cut may be also involved in defining cell identities within es organs, on the basis of the expression pattern of Cut in mutants that affect the lineage of sensory organs (Blochlinger et al. 1990). It has been shown that there is a concentration dependence for homeo domain protein function (Driever and Nüsslein-Volhard 1988; Struhl et al. 1989). Differences in concentration of Cut may be significant for differential regulation of target genes. Experiments to determine whether the identity of neurons and inner support cells can be changed by increasing the concentration of Cut in hsCut flies are in progress.

The expression of the endogenous cut locus is only activated in cells influenced by ectopic Cut expression. This raises the possibility that maintenance of Cut expression may be required for the phenotypic effects. The transformation of ch organs by ectopic Cut expression is incomplete in a mutant background in which the endogenous cut locus produces a nonfunctional cytoplasmic protein. We suspect that the pulse of ectopic Cut expression in this cut mutant causes a transient transforma- tion, which affects the position of the lateral "ch" organs but that the continued presence of a functional Cut protein is required to maintain es organ identity. This is consistent with the fact that Cut expression persists throughout development (Blochlinger et al. 1990; K. Blochlinger, unpubl.).

\section{What determines the specificity of Cut function?}

After heat shock treatment, Cut is synthesized in all cells of the embryos containing the hsCut construct. However, most of the cells appear to be unaffected by the ubiquitous Cut expression. Exceptions are the ch organ cells that assume the identity of es organ cells and the putative tracheal histoblasts whose number increases.

To identify loci involved in defining the specificity of Cut function in peripheral neurogenesis, we determined the effect of ectopic Cut expression in proneural mutants. Our current model of neurogenesis proposes that positional information derived from the genes specifying the primary body axes controls the activation of the proneural genes, whose function is to confer on ectodermal cells the ability to become neural precursors (for review, see Ghysen and Dambly-Chaudiere 1989; Jan and Jan 1990|. The four genes of the $A S-C$ and the $d a$ gene all encode putative transcription factors containing a motif consisting of a helix-loop-helix (HLH) protein dimerization domain and an adjacent basic DNA-binding domain (Villares and Cabrero 1987; Caudy et al. 1988b; Murre et al. 1989). Eliminating the function of any of the identified proneural genes leads to loss of neural tissue in the CNS and the PNS. Evidence from studies of DNA-replication patterns suggests that the PNS precursors in these proneural mutants either do not form or fail to replicate (Bodmer et al. 1989). Several lines of evidence indicate that cut functions subsequent to the proneural genes to specify the individual identities of the neural precursors defined by the latter. Embryos that lack both cut and $A S$-C activity are phenotypically indistinguishable from those mutant only at the $A S-\mathrm{C}$ (R. Bodmer and Y.N. Jan, unpubl.), showing that the $A S-\mathrm{C}$ is epistatic to cut (if the converse were true, the anticipated result would be that es organs would be transformed into ch organs, and as ch organs would not be affected by the lack of $A S$-C activity, no loss of sensory organs would occur). This is corroborated by the temporal aspects of their respective expression patterns (Blochlinger et al. 1990; Cabrera 1990). Finally, no Cut expression is observed in the PNS of $A S-\mathrm{C}$ or da mutant embryos (this report and $\mathrm{K}$. Blochlinger, unpubl.).

Although it is plausible that the proneural genes are directly involved in the activation of Cut expression, it is unlikely that this is their only function because the mutant phenotype of the proneural genes is a loss rather than a transformation of sensory organs. It is possible, however, that instead of the hierarchical relationships implicit in the present model of neurogenesis a crossregulatory network of interactions may be involved, similar to the networks proposed to control segmentation in Drosophila (Carroll 1990) or myogenesis in vertebrates 
(Thayer et al. 1989). To evaluate this possibility we expressed Cut ectopically in embryos lacking the activity of $d a$ and the AS-C. The results described here demonstrate that ectopic Cut expression is insufficient to rescue the formation of es organs in $d a$ or in the $A S-C$ mutants, suggesting that potential cross-regulatory interactions between Cut and the genes regulated by $d a$ and the $A S$-C are unable to obviate the requirement for these proneural genes in es organogenesis. The transformation of ch organs into es organs by ectopic Cut expression, however, still occurs in embryos lacking AS-C activity, illustrating the existence of other loci that can functionally substitute for the $A S$-C in this process. Consistent with the existent model of neurogenesis, the simplest interpretation of our data is that the proneural genes are prerequisite for the formation of neural precursors whose identity is subsequently determined by Cut for other genes involved in selecting neural identity).

rough is another homeo box gene involved in the specification of neural identity; in the developing eye it is required in photoreceptor cells R 2 and R 5 for the correct development of R3 and R4 (Tomlinson et al. 1988). Ectopic expression of rough in $\mathrm{R} 7$ results in its transformation into an R1-R6 photoreceptor cell (Basler et al. 1990; Kimmel et al. 1990). In parallel to cut, this transformation is dependent on the activity of other genes involved in the initiation of neural differentiation (Basler et al. 1990; Kimmel et al. 1990).

\section{Analogy of cut to homeotic selector genes}

The transformations observed by either loss or gain of Cut expression are analogous to those caused by the classic homeotic selector genes, which determine the morphologic characteristics of each body segment or parasegment (Lewis 1978). For example, the homeotic gene Antennapedia (Antp) specifies the identity of the thoracic segments and is normally expressed in the regions giving rise to these segments. Ectopic expression as a result of either gain-of-function mutations or induction of heat shock promoter-Antp fusion genes causes the production of thoracic structures in the place of head structures (Postlethwait and Schneidermann 1971; Frischer et al. 1986; Schneuwly et al. 1987; Gibson and Gehring 1988). Similar results have been obtained by expressing other homeotic genes ectopically (Kuziora and McGinnis 1989; Chadwick et al. 1990; Gibson et al. 1990; Gonzalez-Reyes and Morata 1990; Mann and Hogness 1990).

We have shown here that the ectopic expression of Cut affects only a limited number of cells in the embryo, that is, the function of Cut is specific to those cells. A similar specificity is seen after ubiquitous expression of the classic homeotic selector genes; their ability to effect transformations in metameric identity is restricted to specific segments or parasegments (Schneuwly et al. 1987; Gibson and Gehring 1988; Kuziora and McGinnis 1989; Chadwick et al. 1990; Gibson et al. 1990; GonzalezReyes and Morata 1990; Mann and Hogness 1990|. There is evidence from homeo domain-switching experiments suggesting that the specificity is determined mainly by the homeo domains and adjacent regions (Kuziora and McGinnis 1988, 1989; Gibson et al. 1990; Mann and Hogness 1990). Recent results demonstrating that mammalian homologs of two Drosophila homeotic selector genes result in similar developmental transformation after ectopic expression in flies also indicate that the homeo domain and other conserved regions are sufficient to impart specificity (Malicki et al. 1990; McGinnis et al. 1990). The predicted Cut protein is large (2175 amino acids), and its homeo domain differs significantly from all others (Blochlinger et al. 1988). It will be interesting to determine the regions of the Cut protein involved in restricting its effects to specific cell types.

Another point of similarity between cut and the homeotic selector genes is that their function is required throughout development (for review, see Lawrence 1984) and is thus necessary both for the establishment and the maintenance of the determined state of cells.

It has been suggested that proteins encoded by homeotic selector genes specify metameric identity by regulating the expression of specific target genes (Lewis 1964; Garcia-Bellido 1975; Beachy et al. 1985). All of these proteins contain a homeo domain, and many of them have also been shown to regulate transcription in cultured Drosophila cells /for review, see Hayashi and Scott 1990). The structural and functional similarities of Cut and the homeotic selector genes suggest that Cut regulates the expression of target genes involved in the determination and maintenance of neural identity.

\section{Materials and methods}

hsCut construct

The hsCut construct was obtained by ligating together the cut cDNA sequences in nb5, nb8, e26, rb10, and rb2 to form a contiguous cDNA from nucleotide -268 to 6682 (Blochlinger et al. 1988), which was then inserted into the KpnI site of the p-element vector $\mathrm{pWH1}$. [This vector was constructed by replacing the EcoRI-PstI fragment of pW8 with that of pHT4 (Schneuwly et al. 1987; H. Vaessin, pers. comm.) and sequenced.) The only change in sequence was a $\mathrm{T} \rightarrow \mathrm{C}$ nucleotide change at position 804 , which does not result in an amino acid change.

The hsCut construct was coinjected with the helper plasmid $\mathrm{p} \pi 25.7 \mathrm{wc}$ into embryos of the $w^{1}$ strain (Rubin and Spradling 1982; Karess and Rubin 1984). For most of the analyses, the homozygous viable line $\mathrm{C} 2$ was used, in which the hsCut insertion maps to the second chromosome. For the experiments in the mutant $d a$ background, line B1.4 was used, which contains an hsCut insertion on the $\mathrm{X}$ chromosome.

\section{Drosophila stocks}

All lines containing the hsCut construct were maintained at room temperature. A line homozygous for both the P-element insertion Al 2nd 29 and hsCut on the second chromosome was obtained by recombination. The hsCut transformant line C2 was crossed into $y w c t^{d b 10} / \mathrm{FM}^{3} \mathrm{y}^{31 d} \mathrm{~W}++B$ and maintained homozygous for C2. C2 was also crossed into ${ }^{B 57} w s n^{3} / F M 7$ and maintained heterozygous for $\mathrm{C} 2$ with the $\mathrm{CyO}$ balancer. The hsCut transformant line B1.4 was crossed into $d a^{1(I I)}$ on bw 
$s p / \mathrm{CyO}$ and maintained heterozygous for B1.4 in females with the FM $6 y^{31 d} w++B$ balancer.

\section{Heat shock treatments}

Wild-type and hsCut embryos were collected on grape agar plates for $2 \mathrm{hr}$ at room temperature, aged at room temperature for $5 \mathrm{hr}$, and placed either in a humidified $37^{\circ} \mathrm{C}$ incubator for 30 min or in a humidified $42^{\circ} \mathrm{C}$ incubator twice for $15 \mathrm{~min}$, with an interval of $2 \mathrm{hr}$ at room temperature. The embryos were then aged for an additional $12-14 \mathrm{hr}$ at $18^{\circ} \mathrm{C}$.

For the Western blot analysis, a 1- to 16-hr collection of hsCut embryos on grape agar plates was placed in a humidified $37^{\circ} \mathrm{C}$ incubator for $30 \mathrm{~min}$ and allowed to recover for $30 \mathrm{~min}$ at room temperature.

\section{Western blot analysis}

Embryos were dechorionated in $50 \%$ bleach, washed with $0.7 \%$ $\mathrm{NaCl}, 0.3 \%$ Triton $\mathrm{X}-100$, and homogenized in equal volumes of $0.05 \mathrm{M}$ Tris $\mathrm{HCl}(\mathrm{pH} 8.0), 0.002 \mathrm{M}$ EDTA, $5 \%$ glycerol, $0.001 \mathrm{M}$ phenylmethylsulfonyl fluoride, $20 \mu \mathrm{M}$ benzamidine $\mathrm{HCl}, 2$ $\mu \mathrm{g} / \mathrm{ml}$ of phenanthroline, $20 \mu \mathrm{g} / \mathrm{ml}$ of aprotinin, $20 \mu \mathrm{g} / \mathrm{ml}$ of leupeptin, $20 \mu \mathrm{g} / \mathrm{ml}$ of pepstatin A, and $20 \mu \mathrm{g} / \mathrm{ml}$ of TLCK.

Protein extracts were resolved by electrophoresis through $5 \%$ SDS-polyacrylamide gels (Laemmli 1970) and transferred to nitrocellulose in running buffer containing $20 \%$ methanol. Filters were blocked by incubation in $10 \mathrm{~mm}$ Tris $(\mathrm{pH} 8.0), 30 \mathrm{~mm}$ $\mathrm{NaCl}$, and $0.05 \%$ Tween 20 (TBST) containing $5 \%$ nonfat dry milk for $30-60 \mathrm{~min}$ at $37^{\circ} \mathrm{C}$. Incubations with affinity-purified $\alpha$-Cut antibodies (F2 or clp2; Blochlinger et al. 1990) diluted $1: 200$ in TBST were performed for $3-5 \mathrm{hr}$ at $37^{\circ} \mathrm{C}$. Washes, incubations with alkaline phosphatase-conjugated secondary antibodies (Promega), and alkaline phosphatase reactions were performed according to manufacturers' recommendations.

\section{Immunocytochemistry}

The procedure for whole-mount staining of embryos was described previously (Bodmer et al. 1987). Affinity-purified antiCut antibodies (F2 and clp2; Blochlinger et al. 1990) were diluted $1: 100$. Purified rabbit $\beta$-galactosidase antibodies (Cappel) were diluted $1: 5000$.

\section{Acknowledgments}

We thank Gabrielle Bouliane for help with the microinjections, Ed Grell for his patient support during genetics crises, Rolf Bodmer, Michael Brand, Christine Dambly-Chaudiere, Alain Ghysen, Ed Giniger, Volker Hartenstein, Bill Kimmerly, and Ken Sawin for their critical reading of this manuscript. This study was supported by the Howard Hughes Medical Institute. K.B. had a fellowship from the Swiss National Science Foundation, L.Y.J. and Y.N.J. are Howard Hughes Investigators.

The publication costs of this article were defrayed in part by payment of page charges. This article must therefore be hereby marked "advertisement" in accordance with 18 USC section 1734 solely to indicate this fact.

\section{References}

Basler, K., D. Yen, A. Tomlinson, and E. Hafen. 1990. Reprogramming cell fate in the developing Drosophila retina: Transformation of R7 cells by ectopic expression of rough. Genes \& Dev. 4: 728-739.

Bate, C.M. 1978. Development of sensory systems in arthro- pods. In Handbook of sensory physiology (ed. M. Jacobson), vol. IX, pp. 1-53. Springer-Verlag, Berlin/Heidelberg/New York.

Beachy, P.A., S.L. Helfand, and D.S. Hogness. 1985. Segmental distribution of bithorax complex proteins during Drosophila development. Nature 313: 545-551.

Blochlinger, K., R. Bodmer, J. Jack, L.Y. Jan, and Y.N. Jan. 1988. Primary structure and expression of a product from cut, a locus involved in specifying sensory organ identity in Drosophila. Nature 333: 629-635.

Blochlinger, K., R. Bodmer, L.Y. Jan, and Y.N. Jan. 1990. Patterns of expression of Cut, a protein required for external sensory organ development, in wild-type and cut mutant Drosophila embryos. Genes \& Dev. 4: 1322-1331.

Bodmer, R. and Y.N. Jan. 1987. Morphological differentiation of the embryonic peripheral neurons in Drosophila. Wilhelm Roux's Arch. Dev. Biol. 196: 69-77.

Bodmer, R., S. Barbel, S. Shepherd, J.W. Jack, L.Y. Jan, and Y.N. Jan. 1987. Transformation of sensory organs by mutations of the cut locus of D. melanogaster. Cell 51: 293-307.

Bodmer, R., R. Carretto, and Y.N. Jan. 1989. Neurogenesis of the peripheral nervous system in Drosophila embryos. Neuron 3: $21-32$.

Cabrera, C.V. 1990. Lateral inhibition and cell fate during neurogenesis in Drosophila: The interactions between scute, Notch and Delta. Development 109: 733-742.

Campos-Ortega, J.A. and V. Hartenstein. 1985. The embryonic development of Drosophila melanogaster. Springer-Verlag, Berlin/Heidelberg/New York/Toronto.

Carroll, S.B. 1990. Zebra patterns in fly embryos: Activation of stripes or repression of interstripes. Cell 60:9-16.

Caudy, M., E.H. Grell, C. Dambly-Chaudiere, A. Ghysen, L.Y. Jan, and Y.N. Jan. 1988a. The maternal sex determination gene daughterless has zygotic activity necessary for the formation of peripheral neurons in Drosophila. Genes \& Dev. 2: 843-852.

Caudy, M., H. Vaessin, M. Brand, R. Tuma, L.Y. Jan, and Y.N. Jan. 1988b. daughterless, a Drosophila gene essential for both neurogenesis and sex determination, has sequence similarities to myc and the achaete-scute complex. Cell 55: 1061-1067.

Chadwick, R., B. Jones, T. Jack, and W. McGinnis. 1990. Ectopic expression from the Deformed gene triggers a dominant defect in Drosophila adult head development. Dev. Biol. 141: $130-140$.

Dambly-Chaudiere, C. and A. Ghysen. 1986. The sense organs in the Drosophila larva and their relation to the embryonic pattern of sensory neurons. Wilhelm Roux's Arch. Dev. Biol. 195: 222-228.

- 1987. Independent subpatterns of sense organs require independent genes of the achaete-scute complex in Drosophila larvae. Genes \& Dev. 1: 297-306.

Driever, W. and C. Nüsslein-Volhard. 1988. The bicoid protein determines position in the embryo in a concentration-dependent manner. Cell 54: 95-104.

Frischer, L.E., F.S. Hagen, and R.L. Garber. 1986. An inversion that disrupts the Antennapedia gene causes abnormal structure and localization of RNAs. Cell 47: 1017-1023.

Garcia-Bellido, A. 1975. Genetic control of wing disc development in Drosophila. Ciba Found. Symp. 29: 161-182.

Ghysen, A. and C. Dambly-Chaudiere. 1989. Genesis of the Drosophila peripheral nervous system. Trends Genet. 5: 251-255.

Ghysen, A. and C. O'Kane. 1989. Neural enhancer-like elements as specific cell markers in Drosophila. Development 105: $35-52$. 
Gibson, G. and W.J. Gehring. 1988. Head and thoracic transformation caused by ectopic expression of Antennapedia during Drosophila development. Development 102: 657-675.

Gibson, G., A. Schier, P. LeMotte, and W.J. Gehring. 1990. The specificities of sex combs reduced and Antennapedia are defined by a distinct portion of each protein that includes the homeodomain. Cell 62: 1087-1103.

Gonzalez-Reyes, A. and G. Morata. 1990. The developmental effect of overexpressing a $U b x$ product in Drosophila embryos is dependent on its interactions with other homeotic products. Cell 61: $515-522$.

Hartenstein, V. 1986. Ueber die Struktur und Entwicklung des larvalen peripheren Nervensystems von Drosophila melanogaster. Ph.D. dissertation. Universitaet zu Koeln, Cologne.

- 1988. Development of Drosophila larval sensory organs: Spatiotemporal pattern of sensory neurones, peripheral pathways and sensilla differentiation. Development 102: 869886.

Hartenstein, V. and J.W. Posakony. 1990. Sensillum development in the absence of cell division: The sensillum phenotype of the Drosophila mutant string. Dev. Biol. 138: 147158.

Hayashi, S. and M.P. Scott. 1990. What determines the specificity of action of Drosophila homeodomain proteins? Cell 63: 883-894.

Hertweck, H. 1931. Anatomie und Variabilitaet des Nervensystems and der Sinnesorgane von Drosophila melanogaster (Meigen). Z. Wiss. Zool. 139: 559-663.

Jack, J.W. 1985. Molecular organization of the cut locus of Drosophila melanogaster. Cell 42: 869-876.

Jan, L.Y. and Y.N. Jan. 1982. Antibodies to horseradish peroxidase as specific neuronal markers in Drosophila and in grasshopper embryos. Proc. Natl. Acad. Sci. 72: 2700-2704.

- 1990. Genes required for specifying cell fates in Drosophila embryonic sensory nervous system. Trends Neurosci. 13: 494-498.

Johnson, T.K. and B.H. Judd. 1979. Analysis of the cut locus of Drosophila melanogaster. Genetics 92: 485-502.

Karess, R.E. and G.M. Rubin. 1984. Analysis of P transposable element functions in Drosophila. Cell 38: 135-146.

Kimmel, B.E., U. Heberlein, and G.M. Rubin. 1990. The homeo domain protein rough is expressed in a subset of cells in the developing Drosophila eye where it can specify photoreceptor cell subtype. Genes \& Dev. 4: 712-727.

Kuziora, M.A. and W. McGinnis. 1988. Autoregulation of a Drosophila homeotic selector gene. Cell 55: 477-485.

-1989. A homeodomain substitution changes the regulatory specificity of the Deformed protein in Drosophila embryos. Cell 59: 563-571.

Laemmli, U.K. 1970. Cleavage of structural proteins during the assembly of the head of bacteriophage T4. Nature 227: 680685.

Lawrence, P.A. 1984. Homeotic selector genes-A working definition. Bioessays 1: 227-228.

Lewis, E.B. 1964. Genetic control and regulation of developmental pathways. In The role of chromosomes in development (ed. M. Locke). Academic Press, New York.

- 1978. A gene complex controlling segmentation in Drosophila. Nature 276: 565-570.

Liu, S., E. McLeod, and J. Jack. 1991. Distinct regulatory regions of the cut locus and their effect on cell type specification in Drosophila. Genetics 127: 151-159.

Malicki, J., K. Schughart, and W. McGinnis. 1990. Mouse Hox2.2 specifies thoracic segmental identity in Drosophila embryos and larvae. Cell 63: 961-967.

Mann, R.S. and D.S. Hogness. 1990. Functional dissection of
Ultrabithorax proteins in D. melanogaster. Cell 60: 597610.

McGinnis, N., M.A. Kuziora, and W. McGinnis. 1990. Human Hox-4.2 and Drosophila Deformed encode similar regulatory specificities in Drosophila embryos and larvae. Cell 63: 969976.

McIver, S.B. 1985. Mechanoreception. In Comprehensive insect physiology, biochemistry and pharmacology (ed. G.A. Kerkut and L.I. Gilbert), vol. 6, pp. 71-132. Pergamon Press, New York/London.

Murre, C., P.S. McCaw, H. Vaessin, M. Caudy, L.Y. Jan, Y.N. Jan, C. Cabrera, A.B. Lassar, H. Weintraub, and D. Baltimore. 1989. Interactions between heterologous helix-loop-helix proteins generate complexes that bind specifically to a common DNA sequence. Cell 58: 537-544.

Pollack, J.A. 1985. Monoclonal antibodies staining of Drosophila embryos. Cal. Tech. Biol. Annu. Rep. 203.

Postlethwait, J.H. and H.A. Schneidermann. 1971. Pattern formation and determination in the antenna of the homeotic mutant Antennapedia of Drosophila melanogaster. Dev. Biol. 25: 606-640.

Rubin, G.M. and A.C. Spradling. 1982. Genetic transformation of Drosophila with transposable element vectors. Science 218: $348-353$.

Schneuwly, S., R. Klemenz, and W.J. Gehring. 1987. Redesigning the body plan of Drosophila by ectopic expression of the homeotic gene Antennapedia. Nature 325: 816-818.

Struhl, G., K. Struhl, and P.M. MacDonald. 1989. The gradient morphogen bicoid is a concentration-dependent transcriptional activator. Cell 57: 1259-1273.

Thayer, M.J., S.J. Tapscott, R.L. Davis, W.E. Wright, A.B. Lassar, and $H$. Weintraub. 1989. Positive autoregulation of the myogenic determination gene MyoD1. Cell 58: 241-248.

Tomlinson, A., B.E. Kimmel, and G.M. Rubin. 1988. rough, a Drosophila homeobox gene required in photoreceptors R2 and R5 for inductive interactions in the developing eye. Cell 40: 851-858.

Villares, R. and C.V. Cabrero. 1987. The achaete-scute gene complex of $\mathrm{D}$. melanogaster: Conserved domains in a subset of genes required for neurogenesis and their homology to myc. Cell 50: 415-424.

Zacharuk, R.Y. 1985. Antennae and sensilla. In Comprehensive insect physiology, biochemistry and pharmacology (ed. G.A. Kerkut and L.I. Gilbert), vol. 6, pp. 1-69. Pergamon Press, New York/London.

Zipursky, S.L., T.R. Venkatesh, D.B. Teplow, and S. Benzer. 1984. Neuronal development in the Drosophila retina: Monoclonal antibodies as molecular probes. Cell 36: 15-26. 


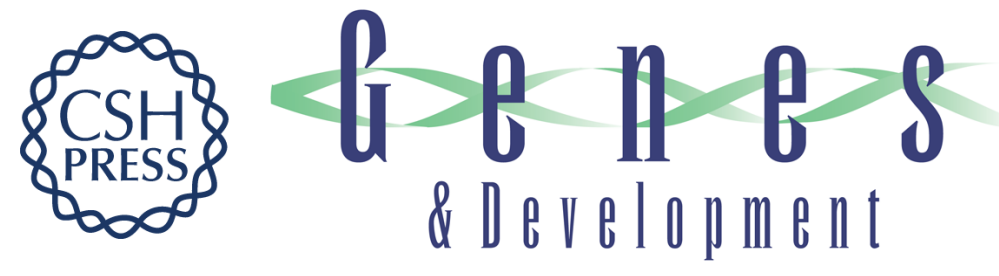

\section{Transformation of sensory organ identity by ectopic expression of Cut in Drosophila.}

$\mathrm{K}$ Blochlinger, $\mathrm{L} Y$ Jan and $\mathrm{Y} N$ Jan

Genes Dev. 1991, 5:

Access the most recent version at doi:10.1101/gad.5.7.1124

References This article cites 50 articles, 12 of which can be accessed free at: http://genesdev.cshlp.org/content/5/7/1124.full.html\#ref-list-1

License

Email Alerting

Service

Receive free email alerts when new articles cite this article - sign up in the box at the top right corner of the article or click here.

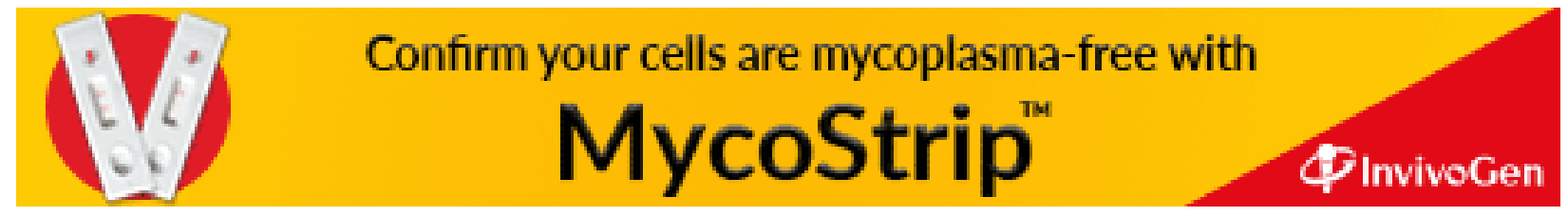

